J. Gen. Appl. Microbiol.

Vol. 8. No. 3, 1962.

\title{
PURIFICATION AND PROPERTIES OF LACTIC DEHYDROGENASE OF LACTOBACILLUS CASEI
}

\author{
SHÔJI MIZUSHIMA and KAKUO KITAHARA \\ The Institute of Applied Microbiology University of Tokyo \\ Received for publication, April 10th, 1962
}

Lactobacillus casei is a lactic acid bacterium which produce only L-lactic acid from glucose. Rather paradoxically, this microorganism was found to possess both $\mathrm{D}$ - and L-lactic acid dehydrogenating activities when tested with 2, 6-dichlorophenol-indophenol as a hydrogen acceptor. Using Lactobacillus thermophilus, which has similar properties, the problem was investigated by KITAHARA and his coworkers, who postulated that the formation of stereospecific lactic acid was caused by the difference in the affinity between the two lactic dehydrogenases towards glyceraldehyde-3-phosphate dehydrogenase (1).

In the present study the problem was reinvestigated for the dehydrogenases of a strain of Lactobacillus casei. It was found that the bacterium contains a DPN-linked lactic dehydrogenase showing only a weak activity, but with a strict specificity towards the D-isomer, and two DPN-independent and flavin-containing dehydrogenases which act upon $\mathrm{D}$ - and L-lactate, respectively. A similar DPN-independent lactic dehydrogenase has been found in some strains of Streptococci (2-5) and was shown to contain flavin nucleotide as prosthetic group. In a certain strain of Lactobacillus casei, KATAGIRI et al (6) demonstrated the presence of an L-latic dehydrogenase, having presumably flavin nucleotide as prosthetic group. In view of the situation that the properties of all these dehydrogenases have not been investigated in their highly purified states, attempts were made to purify the enzymes from Lactobacillus casei by various procedures and to scrutinize their properties, which form the subject of the present paper.

\section{METHODS AND MATERIALS}

Measurement of lactic dehydrogenase activity. The activities of the flavincontaining lactic dehydrogenases were usually estimated by measuring the change of optical density at $600 \mathrm{~m} \mu$ in the presence of 2,6 -dichlorophenolindophenol. Reactions were run in Bechmann type cuvettes $(\mathrm{d}=1 \mathrm{~cm}$.$) , each$ with a total volume of $2.6 \mathrm{ml}$, and readings were made against a biank containing all reactants except $\mathrm{D}$ - or L-lactate. The decrease in optical density at $600 \mathrm{~m} \mu$ was read at 10 -second intervals for 1 to 2 minutes. The reaction mixture contained $0.2 \mathrm{ml}$ of $10^{-3} \mathrm{M}-2$, 6-dichlorophenolindophenol, $2.0 \mathrm{ml}$ of $0.2 \mathrm{M}$-phosphate buffer ( $\mathrm{pH} 5.9$ ) and $0.2 \mathrm{ml}$ of the enzyme solution. The reac- 
tion was started by adding $0.2 \mathrm{ml}$ of $0.1 \mathrm{M}-\mathrm{D}$ - or L-lactate. One activity unit of the enzyme was defined as the amount of enzyme causing a decrease in optical density at $600 \mathrm{~m} \mu$ of 0.1 per minute. The specific activity was expressed at the unit value per $\mathrm{ml}$ of the enzyme preparation showing an optical density of 1.0 at $280 \mathrm{~m} \mu$.

The activity of the DPN-linked lactic dehydrogenase was usually estimated by measuring the change of optical density at $340 \mathrm{~m} \mu$. Reactions were run in BeCKMANN type cuvettes $(\mathrm{d}=1 \mathrm{~cm}$.) with a total volume of $2.6 \mathrm{ml}$, and reading were made against a blank containing all reactants except $\mathrm{D}$-lactate. The decrease in optical density at $340 \mathrm{~m} \mu$ was read at 10 -second intervals for 1 to 2 minutes. The reaction mixture contained $0.2 \mathrm{ml}$ of $0.2 \mathrm{M}$-phosphate buffer ( $\mathrm{pH} 5.9$ ). The reaction was started by adding $0.2 \mathrm{ml}$. of $2 \times 10^{-4} \mathrm{M}-\mathrm{D} \mathrm{PNH}$, $0.2 \mathrm{ml}$ of enzyme solution and $2.0 \mathrm{ml}$ of $10^{-1} \mathrm{M}$-pyruvate. One unit of enzyme was defined as the amount of enzyme causing a decrease in optical density at $340 \mathrm{~m} \mu$ of 0.1 per minute. The specific activity was expressed as units per $\mathrm{ml}$ of the enzyme preparation showing an optical density of 1.0 at $280 \mathrm{~m} \mu$.

Preparation of DEAE-cellulose column. Twenty grams (or $3 \mathrm{~g}$ ) of DEAEcellulose powder (a product of Distillation Products Industries) was mixed with stirring with $400 \mathrm{ml}$ (or $60 \mathrm{ml}$ ) of distilled water, and the mixture was evacuated for 15 minutes using a water pump to remove dissoved air from the solution and the slurry was poured into a colume of $3.6 \mathrm{~cm}$ (or $1.6 \mathrm{~cm}$.) in diameter. After the powder had been packed by gravity to give a column about $20 \mathrm{~cm}$ (or $16 \mathrm{~cm}$.) in height, the column was washed with 10 liters (or 2 liters) of $0.005 \mathrm{M}-\mathrm{KH}_{2} \mathrm{PO}_{4}$ solution. The chromatogram was carried out at room temperature $\left(20-30^{\circ}\right)$.

Cultivation of bacteria Lactobacillus casei was grown at $45^{\circ}$ in a broth (pH 6.5) containing 2 per cent of glucose, 2 per cent of sodium acetate (anhydride), 1 per cent of polypeptone, 1 per cent of meat extract, 0.5 per cent of sodium chloride and 0.1 per cent of yeast extract in tap water. The cultivation was carried out in a tank without aeration. The growth rate of the bacterium was measured using a nepherometer. The bacterial cells were harvested at an early stage of the stationary growth phase (about 300-450 mg dried cells per liter).

Other materials Reduced diphosphopyridine nucleotide (DPNH) was prepared by reducing DPN (a sample from Nutritional Biochemicals Corporation) with alcohol and alcohol dehydrogenase ( 7$)$. Alcohol dehydrogenase was prepared from baker's yeast by the method of RACKER (8). Purified D-amino acid oxidase was kindly supplied from Mr. Ozawa, Faculty of Medicine, University of Nagoya. Calcium phosphate gel was prepared according to the method of MASSay (9).

\section{RESULTS}

Purification procedures of flavin-containing L-lactic dehydrogenase Bacterial cells obtained from 50 liters of culture were washed once with 3 
volumes of 0.5 per cent solution of sodium chloride, suspended in an equal volume of $0.2 \mathrm{M}$-phosphate buffer ( $\mathrm{pH} 5.9$ ) and was exposed to sonic oscillation $(9-10 \mathrm{KC})$ for 20 minutes. The sonicate was centrifuged at $100,000 \times \mathrm{g}$ for 2 hours to remove the intact cells and subcellular particulate fractions. The clear supernatant solution thus obtained was diluted to $800 \mathrm{ml}$ with distilled water to give an optical density of 24 at $280 \mathrm{~m} \mu$. To the diluted solution was added $320 \mathrm{~g}$ of solid ammonium sulfate and the solution was allowed to stand for one hour at $3^{\circ}$. After removing the resultant precipitate by centrifugation, $96 \mathrm{~g}$ of solid ammonium sulfate was further added to the solution. The precipitate formed within one hour was recovered by centrifugation, dissolved in $20 \mathrm{ml}$ of distilled water and dialysed against $0.005 \mathrm{M} \cdot \mathrm{KH}_{2}$ $\mathrm{PO}_{4}$ solution overnight. The dialysed preparation $(30 \mathrm{ml})$ was applied to a column of DEAE cellulose $(3.6 \mathrm{~cm} \times 20 \mathrm{~cm})$. After charging the column with the enzyme, $0.005 \mathrm{M}-\mathrm{KH}_{2} \mathrm{PO}_{4}-0.12 \mathrm{M}-\mathrm{KCl}$ solution was passed through the column at a rate of $2 \mathrm{ml}$ per minute. To the eluates in Tubes No. 130-154 $(10 \mathrm{ml}$ per tube), was added $10 \mathrm{ml}$ of calcium phosphate gel $(200 \mathrm{mg}$ dried weight). After stirring for 10 minutes, the gel was collected by centrifugation, and the enzyme was eluted twice from the gel with $5 \mathrm{ml}$ each of $0.5 \mathrm{M}$ ammonium sulfate. To $11 \mathrm{ml}$ of the eluate was added $6 \mathrm{~g}$ of ammonium sulfate to precipitate the enzyme, which was dissolved in $1 \mathrm{ml}$ of distilled water and then dialyzed against $0.005 \mathrm{M}-\mathrm{KH}_{2} \mathrm{PO}_{4}$ solution for 4 hours. The dialyzed preparation was again applied to a column of DEAE cellulose $(1.5 \mathrm{~cm} \times$ $16 \mathrm{~cm}$ ). After charging the column with the enzyme, $0.005 \mathrm{M}^{-} \mathrm{KH}_{2} \mathrm{PO}_{4}$ $0.12 \mathrm{M}-\mathrm{KCl}$ solution was passed through the column at a rate of $0.4 \mathrm{ml}$ per minute. The enzyme collected in Tubes No. $19-23$ (10 ml per tube) was absorbed on $1 \mathrm{ml}$ of calcium phosphate gel (20 mg dried weight). After removing the solution by a mild centrifugation, the enzyme was twice eluted from the gel with $0.5 \mathrm{ml}$ each of $\mathrm{M}$-ammonium sulfate. The eluate $(1 \mathrm{ml})$ thus obtained was dialyzed against $0.1 \mathrm{M}$-Tris buffer $(\mathrm{pH} 7.4)$ for 3 hours at $3^{\circ}$. The whole procedure of purification which entailed a 310 -fold increase

Table 1. Purification procedures of flavin-containing L-lactic dehydrogenase.

\begin{tabular}{|c|c|c|c|c|c|c|}
\hline Fraction & $\begin{array}{l}\text { Total } \\
\text { volume } \\
(\mathrm{ml})\end{array}$ & $\begin{array}{l}\text { Units } \\
\text { per } \\
\text { ml }\end{array}$ & $\begin{array}{l}\text { Total } \\
\text { units }\end{array}$ & $\begin{array}{l}\mathrm{OD} \\
280 \mathrm{~m} \mu\end{array}$ & $\begin{array}{l}\text { Specific } \\
\text { activity }\end{array}$ & $\begin{array}{l}\text { Recovery } \\
(\%)\end{array}$ \\
\hline Diluted sonicate & 800 & 0.75 & 600 & 25 & 0.03 & 100 \\
\hline $\begin{array}{l}\text { 1st. ammonium sulfate } \\
\text { fractionation }\end{array}$ & 14 & 42.8 & 600 & 122 & 0.35 & 100 \\
\hline $\begin{array}{l}\text { 1st. DEAE cellulose } \\
\text { chromatogram }\end{array}$ & 260 & 1.40 & 365 & 0.194 & 7.2 & 61 \\
\hline $\begin{array}{l}\text { 2nd. DEAE cellulose } \\
\text { chromatogram }\end{array}$ & 50 & 2.24 & 112 & 0.244 & 9.2 & 19 \\
\hline
\end{tabular}


of the specific enzyme activity of the preparation, is summarized in Table 1. By the ultracentrifugal analysis it was revealed that the purity of the finaly obtained preparation was approximately 90 per cent (see Fig. 1).
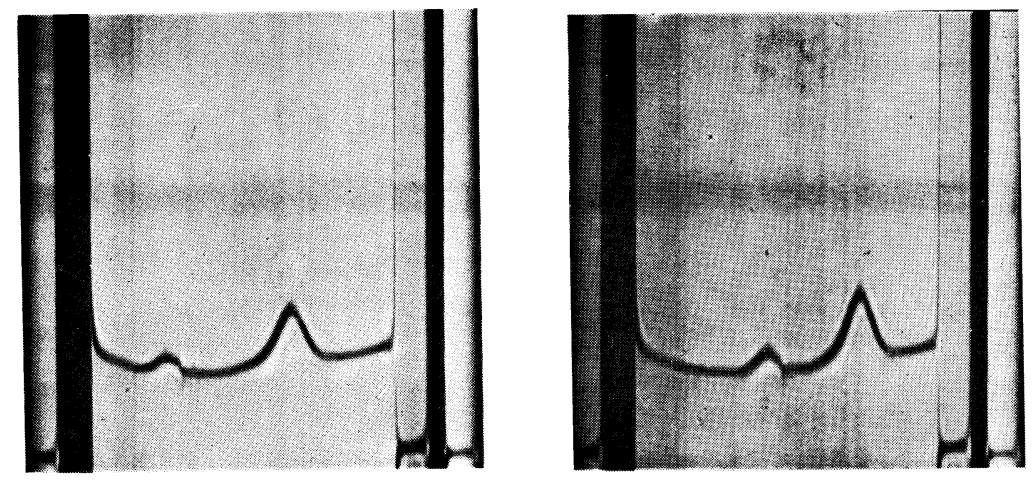

Fig. 1. Sedimentation pattern of purified flavin-containing L-lactic dehydrogenase in a Spinco ultracentrifuge.

Buffer: $0.2 \mathrm{M}$-Tris buffer (pH 7.4); temperature: $11.8-12.0^{\circ}$, speed: 59,200 r.p.m.; bar angle: $60^{\circ}$. The two exposures were spaced 16 minutes apart. A yellowish por. tion was always found at the left hand side of the main boundary.

Purification procedures of flavin-containing D-lactic dehydrogenase Four hundred $\mathrm{ml}$ of the sonicate obtained from $200 \mathrm{~g}$ of wet bacterial cells was also used as the source of the enzyme. After removing the subcellular particulate fraction by ultracentrifugation, the clear supernatant solution was diluted to 1.21 with distilled water to reach an optical density of 24 at $280 \mathrm{~m} \mu$. To the diluted solution was added $336 \mathrm{~g}$ of solid ammonium sulfate, and the solution was allowed to stand for one hour at $3^{\circ}$. After removing the resultant precipitate by centrifugation, $84 \mathrm{~g}$ of solid ammonium sulfate was added to the solution, and the precipitate formed within one hour was collected by centrifugation. This precipitate was dissolved in distilled water to make a total volume of $400 \mathrm{ml}$, and the enzyme was further purified by fractionating salting out with solid ammonium salfate as follows. First $100 \mathrm{~g}$ of ammonium sulfate was added to the solution, and after standing for one hour the resultant precipitate was centrifuged off; then, $140 \mathrm{~g}$ of ammonium salfate was added, and the precipitate formed within one hour was collected by centrifugation, dissolved in $20 \mathrm{ml}$ of distilled water, and dialyzed against 21 of $0.005 \mathrm{M}-\mathrm{KH}_{2} \mathrm{PO}_{4}$ solution for 6 hours at $3^{\circ}$. The dialyzed preparation $(30 \mathrm{ml})$ was applied to a column of DEAE cellulose $(3.6 \mathrm{~cm} \times 20 \mathrm{~cm})$. After charging the column with the enzyme solution, $0.005 \mathrm{M}-\mathrm{KH}_{2} \mathrm{PO}_{4}-0.15 \mathrm{M}$ $\mathrm{KCl}$ solution was passed through the column at a rate of $2 \mathrm{ml}$ per minute. To the eluates in Tubes No. $56-60$ (10 $\mathrm{ml}$ per tube), was added $5 \mathrm{ml}$ of calcium phosphate gel (100 mg dried weight). Then the gel was collected 
by centrifugation and the supernatant solution was again treated with an equal amount of the gel. Both gel fractions were combined, and the enzyme absorbed on the gel was eluted three times with 5,3 , and $3 \mathrm{ml}$ of $\mathrm{M}$-ammonium sulfate solution, respectively. To $13 \mathrm{ml}$ of the eluate thus obtained, was added $4.8 \mathrm{~g}$ of solid ammonium sulfate, and the precipitate formed within one hour was dissolved in $1 \mathrm{ml}$ of distilled water and dialyzed against $0.005 \mathrm{M}-\mathrm{KH}_{2} \mathrm{PO}_{4}$ solution for 6 hours at $5^{\circ}$. The dialyzate was again applied to a column of DEAE collulose $(1.5 \mathrm{~cm} \times 16 \mathrm{~cm})$. After charging the column with the enzyme, $0.005 \mathrm{M}-\mathrm{KH}_{2} \mathrm{PO}_{4}-0.15 \mathrm{M}-\mathrm{KCl}$ solution was passed through the column at a rate of $0.4 \mathrm{ml}$ per minute. The enzyme collected in Tubes No. 31-39 (10 $\mathrm{ml}$ per tube) was absorbed on calcium phosphate gel $(100 \mathrm{mg}$ dried weight), then eluted with $2.8 \mathrm{ml}$ of $\mathrm{M}$-ammonium sulfate solution, and dialyzed against $\mathrm{M} / 10$-Tris buffer ( $\mathrm{pH} 7.4$ ) for 3 hours at $3^{\circ}$. The whole procedures described above, by which 400 fold increase of the specific activity of the enzyme preparation could be achieved, is summarized in Table 2. Examination on an analytical ultracentrifuge revealed that the enzyme preparation thus purified had a purity of approximately 90 per cent.

Table 2. Purification procedures of flavin-containing D-lactic dehydrogenase.

\begin{tabular}{|c|c|c|c|c|c|c|}
\hline Fraction & $\begin{array}{l}\text { Total } \\
\text { volume } \\
(\mathrm{ml})\end{array}$ & $\begin{array}{l}\text { Units } \\
\text { per ml }\end{array}$ & $\begin{array}{l}\text { Total } \\
\text { units }\end{array}$ & $\begin{array}{l}\mathrm{OD} \\
280 \mathrm{~m} \mu\end{array}$ & $\begin{array}{l}\text { Specific } \\
\text { activity }\end{array}$ & $\underset{(\%)}{\operatorname{Recover}}$ \\
\hline $\begin{array}{l}\text { Sonicate after } \\
\text { ultracentrifugation }\end{array}$ & 250 & 0.80 & 200 & 176 & 0.00455 & 100 \\
\hline $\begin{array}{l}\text { 1st ammonium sulfate } \\
\text { fractionation }\end{array}$ & 400 & 0.41 & 165 & 25 & 0.0164 & 83 \\
\hline $\begin{array}{l}\text { 2nd ammonium sulfate } \\
\text { fractionation }\end{array}$ & 20 & 7.6 & 153 & 180 & 0.0422 & 76 \\
\hline $\begin{array}{l}\text { 1st DEAE cellulose } \\
\text { chromatogram }\end{array}$ & 50 & 0.84 & 42 & 0.84 & 1.00 & 21 \\
\hline $\begin{array}{l}\text { 2nd DEAE cellulose } \\
\text { chromatogram }\end{array}$ & 40 & 0.41 & 16.5 & 0.225 & 1.82 & 8.3 \\
\hline Final preparation & 3.0 & 3.0 & 9.0 & 1.65 & 1.82 & 4.5 \\
\hline
\end{tabular}

Purification procedure of DPN-linked D.lactic dehydrogenase Fourty $\mathrm{ml}$ of the sonicate obtained from $15 \mathrm{~g}$ of wet bacterial cells was used as enzyme source. After removing the subcellular particulate fractions by ultracentrifugation, the clear supernatant solution was diluted to $100 \mathrm{ml}$ with distilled water. To the diluted solution, was added $32.5 \mathrm{~g}$ of solid ammonium sulfate, and the solution was allowed to stand for 1 hour at $3^{\circ}$. After removing the resultant precipitate by centrifugation, $7.5 \mathrm{~g}$ of solid ammonium sulfate was added to the solution, and after one hour the precipitate formed was collected 
Table 3. Purification procedures of DPN-linked D-lactic dehydrogenase.

\begin{tabular}{l|cc|c|c|c|c}
\hline \multicolumn{1}{c|}{ Fraction } & $\begin{array}{c}\text { Total } \\
\text { volume } \\
(\mathrm{ml})\end{array}$ & $\begin{array}{c}\text { Unit } \\
\text { per ml }\end{array}$ & $\begin{array}{c}\text { Total } \\
\text { units }\end{array}$ & $\begin{array}{c}\text { OD } \\
280 \mathrm{~m} \mu\end{array}$ & $\begin{array}{c}\text { Specific } \\
\text { activity }\end{array}$ & $\begin{array}{c}\text { Recovery } \\
(\%)\end{array}$ \\
\hline Sonicate & 37 & 69 & 2550 & - & - & 100 \\
$\begin{array}{c}\text { After ultracent- } \\
\text { rifugation }\end{array}$ & 37 & 69 & 2550 & 48 & 1.44 & 100 \\
$\begin{array}{c}\text { Ammonium sulfate } \\
\text { fractionation }\end{array}$ & 7 & 150 & 1050 & 20 & 7.5 & 41 \\
$\begin{array}{c}\text { DEAE cellulose } \\
\text { chromatogram }\end{array}$ & 30 & 18 & 540 & 0.26 & 69.3 & 21 \\
\end{tabular}

by centrifugation. The precipitate was dissolved in $5 \mathrm{ml}$ of distilled water, and dialyzed against $0.005 \mathrm{M}-\mathrm{KH}_{2} \mathrm{PO}_{4}$ solution overnight. The dialyzed preparation $(7 \mathrm{ml})$ was applied to a column of DEAE cellulose $(1.5 \mathrm{~cm}$ $\times 16 \mathrm{~cm}$ ). After charging the column with the enzyme, $100 \mathrm{ml}$ of $0.005 \mathrm{M}$ $\mathrm{KH}_{2} \mathrm{PO}_{4}^{-}-0.1 \mathrm{M}-\mathrm{KCl}$ solution was passed through the column at a rate of $1 \mathrm{ml}$ per minute. The eluate in Tubes No. 13-15 (10 $\mathrm{ml}$ per tube) was used as a partially purified D-lactic dehydrogenase preparation. In Table 3 is summarized the course of purification procedure, which enabled us to increase the specific activity of enzyme preparation by 50-fold. Although the final preparation was not homogeneous, it showed no activity towards $\mathrm{D}$ - and $\mathrm{L}$-lactate when 2,6-dichlorophenolindophenol was used as an electron acceptor.

Properties of the flavin-containing $D$. and L-lactic dehydrogenase

1) Optimal $\mathrm{pH}$ : Effect of $\mathrm{pH}$ on the activities of these enzymes is shown in Fig. 2, from which it may be seen that the optimal $\mathrm{pH}$ for $\mathrm{D}$. and L-lactic dehydrognenases lies at 6.3 and 5.6, respectively.

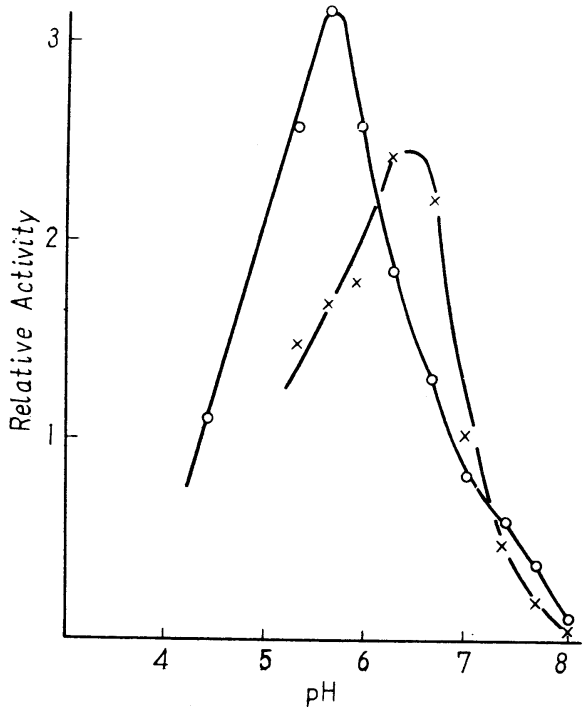

Fig. 2. Effect of $\mathrm{pH}$ on activities of flavin-containing $\mathrm{D}$ - and L-lactic dehydrogenases.

Each photo-cuvette contained $0.2 \mathrm{ml}$ of diluted enzyme, $0.2 \mathrm{ml}$ of $10^{-3} \mathrm{M} \mathrm{2,6-}$ dichlorophenolindophenol and $2.0 \mathrm{ml}$ of $\mathrm{M}$ / 15-phosphate buffer. The reaction was started by adding $0.2 \mathrm{ml}$ of $0.1 \mathrm{M} \mathrm{D}$ - or L-lactate.

-O- L-lactic dehydrogenase,

- - D-lactic dehydrogenase. 


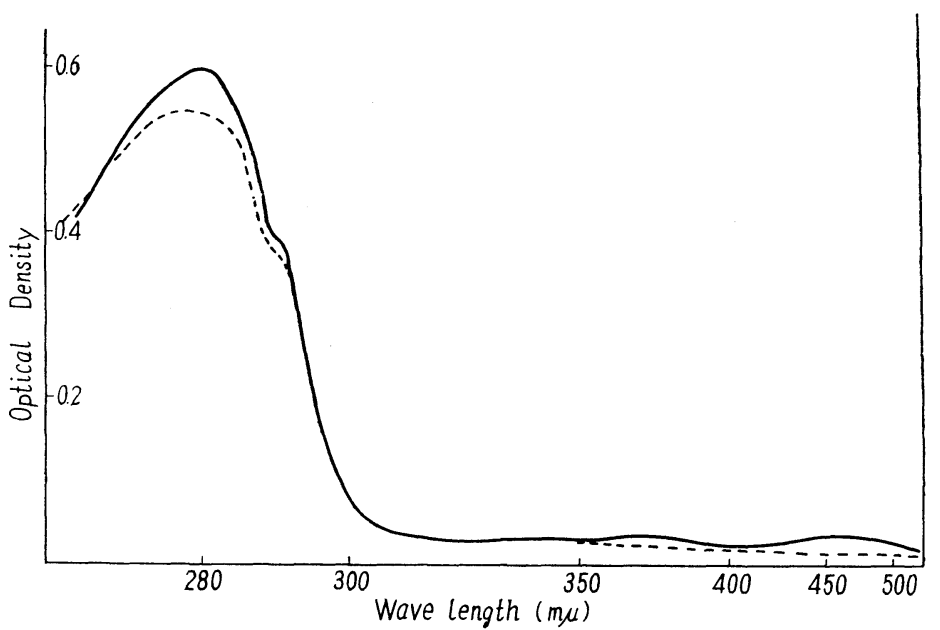

Fig. 3. Absorption spectrum of flavin-containing L-lactic dehydrogenase.

The reduced spectrum was obtained after the addition of $20 \mu \mathrm{M}$ of L-lactate in $2.5 \mathrm{ml}$ of enzyme solution. oxidized. - - - - reduced.

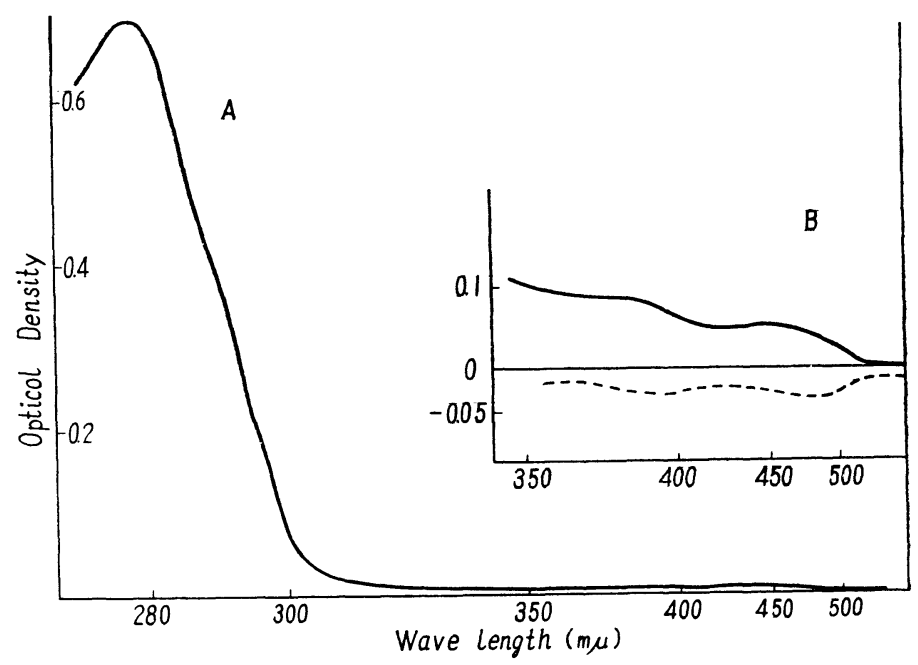

Fig. 4. Absorption spectrum of flavin-containing D-lactic dehydrogenase.

The reduced spectrum was obtained after the addition of 20 $\mu \mathrm{M}$ of $\mathrm{D}$-lactate in $2.5 \mathrm{ml}$ of enzyme solution. oxidized. - - - - - reduced-oxidized.

A: diluted preparation, B: concentrated preparation. 
2) Michaelis constant: The $\mathrm{Km}$ for the dehydrogenation of $\mathrm{L}$-lactate by $\mathrm{L}$-lactic dehydrogenase was found to be $1.4 \times 10^{-2} \mathrm{M}$, while the corresponding value for the dehydrogenation of $\mathrm{D}$-lactate by $\mathrm{D}$-lactic dehydrogenase was $6 \times 10^{-4} \mathrm{M}$.

3) Activation energy: The activation energy for the dehydrogenation of L-lactate was found to be $9730 \mathrm{cal}$. and $21550 \mathrm{cal}$. in the ranges from $30^{\circ}$ to $20^{\circ}$ and from $20^{\circ}$ to $13^{\circ}$, respectively.

4) Stoichiometry of the reaction: Both enzymes dehydrogenated lactate to give pyruvate quantitatively in the presence of 2, 6-dichlorophenolindophenol, corresponding to the equation:

D-(or L-)lactate + dye $\longrightarrow$ pyruvate + reduced dye

5) Prosthetic group: In Figs. 3 and 4 are shown the absorption spectra of $\mathrm{D}$ - and L-lactic dehydrogenases; the former showed maxima at 465,385 , $277 \mathrm{~m} \mu$ and the latter at $455,375,280 \mathrm{~m} \mu$ (with a shoulder at around $290 \mathrm{~m} \mu$ ), both spectra being typical of flavoprotein. On adding $\mathrm{D}$ - or L-lactate the enzymes were rapidly reduced loosing peaks at around 460 and $380 \mathrm{~m} \mu$. Attempts at releasing reversibly the flavin moieties from the holo-enzymes were unsuccessful. To know whether the prosthetic groups are FAD, tests were made of the effects of the heated enzymes upon the activity of purified D-amino acid oxidase, which is specific for FAD. As shown in Table 4 , the heated preparation of $\mathrm{D}$-lactic dehydrogenase reactivated the apo-Damino acid oxidase to the same degree as authentic FAD, when compared

Table 4. Effect of heated preparation of flavin-containing D- and L-lactic dehydrogenases on apo-D-amino acid oxidase.

\begin{tabular}{|c|c|}
\hline Addition & $\mathrm{O}_{2}$ uptake in $25 \mathrm{~min}$. \\
\hline D-amino acid oxidase + D-alanine & $2 \mu 1$ \\
\hline $\begin{array}{l}\text { D-amino acid oxidase }+\mathrm{D} \text {-alanine }+ \text { heated } \mathrm{D} \text {-enzyme } \\
\quad \text { (containing } 3 \times 10^{-9} \mathrm{M} \text { flavin nucleotide) }\end{array}$ & 27 \\
\hline D-amino acid oxidase + D-alanine + FAD $\left(3 \times 10^{-9} \mathrm{M}\right)$ & 27 \\
\hline D-amino acid oxidase + D-alanine & 7 \\
\hline $\begin{array}{l}\text { D-amino acid oxidase }+ \text { D-alanine }+ \text { heated L-enzyme } \\
\quad \text { (containing } 6 \times 10^{-10} \mathrm{M} \text { flavin nucleotide) }\end{array}$ & 7 \\
\hline D-amino acid oxidase + D-alanine + FAD $\left(6 \times 10^{-10} \mathrm{M}\right)$ & 15 \\
\hline
\end{tabular}

The reactions were carried out in Warburg vessels at $30^{\circ}$. Each vessel contained $0.5 \mathrm{ml}$ of heated enzyme or FAD, $0.2 \mathrm{ml}$ of $\mathrm{D}$-amino acid oxidase and $2.0 \mathrm{ml}$ of $0.2 \mathrm{M}$ $\mathrm{Na}_{2} \mathrm{HPO}_{4}$ in the main compartment, $0.2 \mathrm{ml}$ of $0.2 \mathrm{M}$-D-alanine in the side arm and 0.2 $\mathrm{ml}$ of $20 \% \mathrm{KOH}$ in the center well. 
by the absorption at $450 \mathrm{~m} \mu$. On the other hand, the heated preparation of L-lactic dehydrogenase had no effect on apo-D-amino acid oxidase. By estimating the amount of active flavin in the enzyme from the difference (oxidized minus reduced) in its optical density at $450 \mathrm{~m} \mu$, the turnover number of $\mathrm{D}$ - and L-lactic dehydrogenase was found to be approximately 5000 and 1300 per minute per mole of flavin at $20^{\circ}$, respectively.

6) Specificity of electron acceptor: In the presence of $\mathrm{D}$-lactate, D-lactic dehydrogenase reduced 2,6-dichlorophenolindophenol and methylene blue but not oxygen. L-Lactic dehydrogenase, on the other hand, could reduce only 2, 6-dichlorophenolindophenol in the presence of L-lactate.

7) Effect of atabrine on enzyme activity: As shown in Table 5, atabrine showed a relatively strong inhibitory effect on L-lactic dehydrogenase, but

Table 5. Effect of atabrine on the activities of flavin-containing enzymes.

Enzyme $\quad$ Atabrine concentration $\quad$ Inhibition \%

L-lactic dehydrogenase

D-Lactic dehydrogenase

$\begin{array}{lr}10^{-2} \mathrm{M} & 82 \\ 10^{-3} \mathrm{M} & 62 \\ 10^{-3} \mathrm{M} & 0\end{array}$

Each cuvette contained $0.2 \mathrm{ml}$ of diluted enzyme, $0.2 \mathrm{ml}$ of inhibitor, $0.2 \mathrm{ml}$ of $10^{-3}$ M 2, 6-dichlorophenolindophenol and $2.0 \mathrm{ml}$ of $0.2 \mathrm{M}$-phosphate buffer ( $\mathrm{pH} \mathrm{5.9).} \mathrm{Reac-}$ tions were started by the addition of $0.2 \mathrm{ml}$ of $0.1 \mathrm{M} \mathrm{D}$ - cr L-lactate.

Table 6. Comparison of properties of flavin-containing D- and L-lactic dehydrogenases.

D-lactic dehydrogenase

6.3

$$
\begin{gathered}
6 \times 10^{-4} \mathrm{M} / \mathrm{L} \\
460-470 \\
380-390 \\
277
\end{gathered}
$$

FAD

5000

\section{L-lactic dehydrogenase}

$$
5.6
$$

$$
1.4 \times 10^{-2} \mathrm{M} \mathrm{L}
$$

450-460

370-390

280

(290 shoulder)

FMN (?) $+\alpha$

1300

Turnover number

2, 6-dichlorophenolindophenol, 2, 6-dichlorophenolindomethylene blue

phenol,

Inhibition by atabrine $\left(10^{-3} \mathrm{M}\right)$

$0 \%$

$62 \%$ 
had no effect on D-lactic dehydrogenase. This inhibitory effect was not depreesed by the addition of FAD or FMN.

8) Reversibility of L-lactic dehydrogenase: L-Lactic dehydrogenase was found to mediate the reduction of pyruvate to lactate in the presence of reduced methylviologen at $\mathrm{pH} 5.9$, indicating a reversibility of the enzyme reaction. No such back reaction could be detected with $\mathrm{D}$-lactic dehydrogenase, placed under the same condition.

Properties of the two enzymes described above are summarized in Table 6.

Properties of DPN-linked D-lactic dehydrogenase As shown in Fig. 5, this enzyme catalyzes the reduction of DPN in the presence of D-lactate but not in the presence of L-lactate. From the data presented in Fig. 5, the equilibrium constant of this $\mathrm{D}$-lactic dehydrogenase reaction was calculated as follow;

$$
\frac{(\text { pyruvate })(\mathrm{DPNH})\left(\mathrm{H}^{+}\right)}{\text {(lactate })\left(\mathrm{DPN}^{+}\right)}=4.5 \times 10^{-13}
$$

The enzyme was found to be specific for DPN, showing no reactivity towards TPN. The $\mathrm{Km}$ for the reduction of pyruvate and for the dehydrogenation of DPNH by the enzyme was found to be $1 \times 10^{-2} \mathrm{M}$ and $1 \times 10^{-6} \mathrm{M}$ at $\mathrm{pH} 5.9$, respectively.

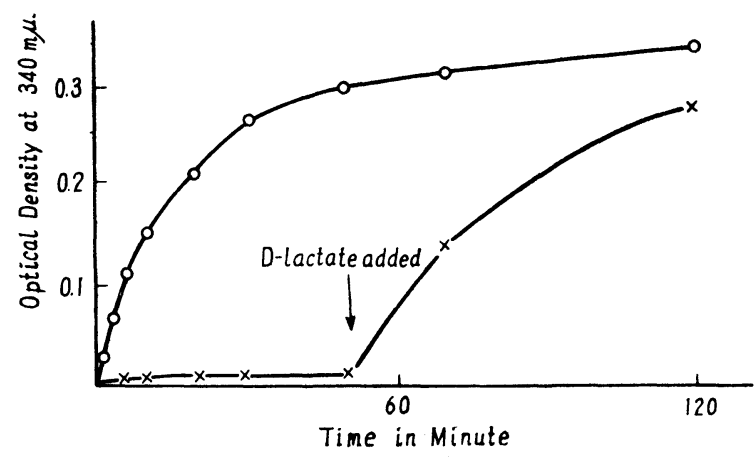

Fig. 5. Reduction of DPN by DPN-linked lactic dehydrogenase.

Each photo-cuvette contained: $1 \mathrm{ml}$ of diluted enzyme, $5 \mu \mathrm{M}$ of DPN and $1.7 \mathrm{ml}$ (for L-lactate) or $1.9 \mathrm{ml}$ (for D-lactate) of $0.2 \mathrm{M}-\mathrm{Na}_{2} \mathrm{HPO}_{4}$ solution. Reactions were started by the addition of $0.3 \mathrm{ml}$ of 0.1 M L-lactate $(-\times-)$ or $0.1 \mathrm{ml}$ of M-D-lactate (- --$)$.

\section{DISCUSSION}

The results described above show that the strain of Lactobacillus casei studied in the present work possesses three kinds of lactic dehydrogenase; 
namely (i) flavin-containing $\mathrm{D}$-lactic dehydrogenase, (ii) flavin-containing $\mathrm{L}$ lactic dehydrogenase and (iii) DPN-linked D-lactic dehydrogenase. The former two enzymes share the properties of possessing flavin nucleotide as prosthetic group and of lacking the ability to react with DPN. In other respects, such as the substrate specificity, the $\mathrm{Km}$ value, the specificity towards electron acceptors, the susceptivity towards atabrine etc., they are profoundly different as summarized in Table 6 . The prosthetic group of the D-lactic dehydrogenase was identified as FAD, while that of L-lactic dehydrogenase was concluded to be something other than FAD. It should be remarked that during the purification of the latter enzyme an inactivated preparation was obtained by chance, and the activity of this preparation was restored by the addition of heated sonicate of bacterial cells but not by the following eleven co-factors tested: FAD, FMN, DPN, TPN, CoA, lipoate, vitamine $B_{1}, B_{2}, B_{12}$, biotin and ascorbate. These observations suggests that the enzyme may have some other cofactor in addition to flavin nucleotide. An L-lactic dehydrogenase has also been obtained by KATAGIRI et al (6), in a partially purified state, from a different strain of Lactobaci'lus casei and based on some evidences it was concluded to contain a flavin mononucleotide as prosthetic group. MoYED and O'KANE found in Lactobacilius bulgaricus (5) also an L-lactic dehydrogenase which could not react with DPN. These enzymes appear to be similar in their nature of prosthetic group and specificity to electron acceptors to the L-lactic dehydrogenase described above.

The DPN-linked lactic dehydrogenase which we have isolated from the sonicate of bacterial cells was specific only to D-lactate. We could not succeed in purifying this enzyme to a satisfactory degree, although in some experiments, more than 90 per cent of the enzyme could be recovered through DEAE cellulose chromatogram or ammonium sulfate fractionation. Thus far no evidence could be obtained showing the existance of a DPNlinked lactic dehydrogenase specific for L-isomer.

As described in the INTRODUCTION, the bacterium used in the present study can form only L-lactate. The fact that the bacterium is lacking in the DPN-linked L-lactic dehydrogenase compels us to think about the possibility of the participation of flavin containing L-lactic dehydrogenase in the fermentation. This view seems to be further strengthened by the following facts; a) the fermentation by resting cells and the activity of the flavincontaining L-lactic dehydrogenase were inhibited by $10^{-3} \mathrm{M}$ of atabrine to almost the same degree $(10), \mathrm{b})$ the enzyme was proved to have an ability of reducing pyruvate to lactate, and c) the enzyme showed a low affinity towards lactate which is the product of the fermentation.

The role of DPN-linked D-lactic dehydrogenase in living bacterial cells is also a matter worthy of consideration. Judging from its $\mathrm{Km}$ values for DPNH and pyruvate and the concentration of DPNH and pyruvate found in intact cells, the activity of the enzyme in vivo is estimated to be about $4 \mu \mathrm{M} / \mathrm{mg}$ cells/min.. This value is higher than the L-lactate forming activity 
of the intact cells (about $2 \mu \mathrm{M} / \mathrm{mg}$ cells $/ \mathrm{min}$ ) (10). The fact that, nevertheless, the intact cells of the organism do not produce a detectable amount of D-lactate, may be explained only by invoking a certain specific controlling mechanism operating in the metabolism of the cells.

\section{SUMMARY}

1. From the cells of a strain of Lactobacillus casei, three kinds of lactic dehydrogenase were isolated. These are (i) a flavin-containing D-lactic dehydrogenase, (ii) a flavin-containing L-lactic dehydrognease and (iii) a DPNlinked D-lactic dehydrogenase. The former two were purified to almost homogeneous states.

2. These two enzyme showed, besides the difference in their substrate specificity, differences in their $\mathrm{Km}$ value, in their specificity towards electron acceptor and in their susceptivity towards atabrine. The prosthetic group of the D-enzyme was identified as FAD, while that of the L-enzyme was concluded to be some flavine nucleotide other than FAD.

3. Whereas the presence of a DPN-linked D-lactic dehydrogenase was confirmed beyond all doubt, no evidence whatsoever could be obtained for the existence of a DPN-linked L-enzyme. The absence of the latter enzyme was surprising in view of the fact that the bacterium used in the present study is a producer of L-lactic acid only.

4. The possible role of the flavin-containing L-lactic dehydrogenase in the L-lactic acid fermentation of this bacteria was discussed.

\section{ACKNOWLEDGEMENT}

The large scale cultivation was carried out through the courtesy of Kyowa Fermentation Industry Co. Ltd.

\section{REFERENCES}

(1) K. Kitahara, S. FukUi and A. Obayashi: Symp. Enzyme Chem. (Japan) 10, 210 (1954).

(2) W. B. Sutton: J. Biol. Chem., 226, 395 (1957).

(3) L. P. Hager, D. M. Celler and F. Lipmann: Fed. Proc. 13, 734 (1954).

(4) J. Szulmajester, M. Grunberg-Mango and C. Delavier-Klutchkor: Bull. Ste. Chim. Biol. 35, 1381 (1953).

(5) H. S. Moyed and D. J. O'Kane: Bacteriol. Proc. 96 (1954).

(6) H. Katagiri, T. ImaI and H. AnyoJi: Symp. Enzyme Chem. (Japan) 14, 99 (1960).

(7) S. P. Colowick and N. O. Kaplan: Method in Enzymology. Academic Press. Inc. New York, Vol. III p. 887 (1957).

(8) E. RaCker: J. Biol. Chem. 184, 313 (1950).

(9) V. MASSAY: Biochim. et Biophys. Acta. 37, 310 (1960).

(10) Umpablished observations. 